Www.jmscr.igmpublication.org

Index Copernicus Value: 79.54

ISSN (e)-2347-176x ISSN (p) 2455-0450

crossref DOI: https://dx.doi.org/10.18535/jmscr/v7i3.212

\title{
Measurement of Serum Amylase in Correlation with Plasma Cholinesterase Level for Assessing the Severity of Organophosphorus Poisoning
}

\author{
Authors
}

\author{
Dr M. Ramesh MD, Dr Thenmozhi MD
}

\begin{abstract}
Background and Objectives: Organophosphate $(O P)$ compound poisoning is the most commonly encountered poisoning in tertiary care hospital. Previously plasma cholinesterase level was used for predicting the severity of poisoning. It was also used to determine the clinical course. Recently serum amylase is being recommended as a better predictor of severity of poisoning. Hence in this study measurement of serum amylase in correlation with plasma cholinesterase level is being studied for assessing the severity of Organophosphate compound poisoning.

Methods: A prospective study was conducted on 100 patients admitted to emergency ward and Intensive care unit in tertiary care hospital. Serum amylase and Plasma cholinesterase levels were measured at the time of admission and at 48 hours.

Results: This Study revealed that there is significant elevation of amylase and inhibition of cholinesterase at admission and at 48 hours in OPC poisoning patients. The overall mean value for amylase was $712.66 \mathrm{U} / \mathrm{L}$ at admission $(660 \mathrm{U} / \mathrm{L}$ in survivors $\mathrm{Vs} 835.13 \mathrm{U} / \mathrm{L}$ in non-survivors, $p<0.001)$. The overall mean value for plasma cholinesterase was $1958.78 \mathrm{U} / \mathrm{L}$ at admission (2236.54 U/L in survivors Vs $1310.67 \mathrm{U} / \mathrm{L}$ in non-survivors, $p<0.05)$. The overall mean value for amylase was $401.62 \mathrm{U} / \mathrm{L}$ at 48 hours $(248.71 \mathrm{U}$ in survivors $V s 758.40 \mathrm{U}$ in non-survivors, $p<0.001)$. The overall mean value for plasma cholinesterase was $3524.06 \mathrm{U} / \mathrm{L}$ at 48 hours. (4358.70 U/L in survivors Vs 1576.57 U/L in non-survivors, $p<0.05$ ).

Interpretation: The elevation of serum amylase in OP intoxicated patients can provide a high degree of prediction for subsequent respiratory failure and mortality. In such cases quick transfer of the patient to a intensive care unit will reduce the degree of mortality associated with OP poisoning.

Keywords: Organophosphate poisoning, serum amylase, plasma cholinesterase.
\end{abstract}

\section{Introduction}

During the past few decades thousands of organophosphorus compounds have been identified. Among these compounds around hundred of them have been used for its insecticidal activity in agriculture ${ }^{1}$.

Among these, suicidal poisoning is the commonest mode of poisoning in developing countries $^{2}$. Organophosphorus and organocarbamate insecticides inhibit the enzyme acetyl cholinesterase. It leads to the accumulation of acetylcholine. It binds to muscarinic and nicotinic receptors in the nervous system. Signs and symptoms of poisoning occurs as a result of continuous acetylcholine stimulation at receptor sites.

There are two forms of cholinesterases.

1. True cholinesterase or acetyl cholinesterase. It 
is located in RBC s, neuromuscular junctions and gray matter of brain.

2. Pseudocholinesterase, serum or plasma cholinesterase. It is mainly present in serum. But it is also present in liver, pancreas and heart ${ }^{3}$.

Both these forms are inhibited by the organophosphorus compounds.

This study evaluates the significance of measuring the serum amylase in correlation with serum cholinesterase level for predicting the severity of organophosphorus poisoning.

\section{Aims and Objectives}

1. To measure serum amylase and pseudocholinesterase level in organophosphorus poisoning at the time of admission and at 48 hours.

2. To compare serum amylase and pseudocholinesterase level with duration of hospital stay.

3. To compare serum amylase and pseudocholinesterase level with duration of ventilator support.

4. To compare serum amylase and pseudocholinesterase level with outcome.

5. To compare serum amylase with pseudocholinesterase level

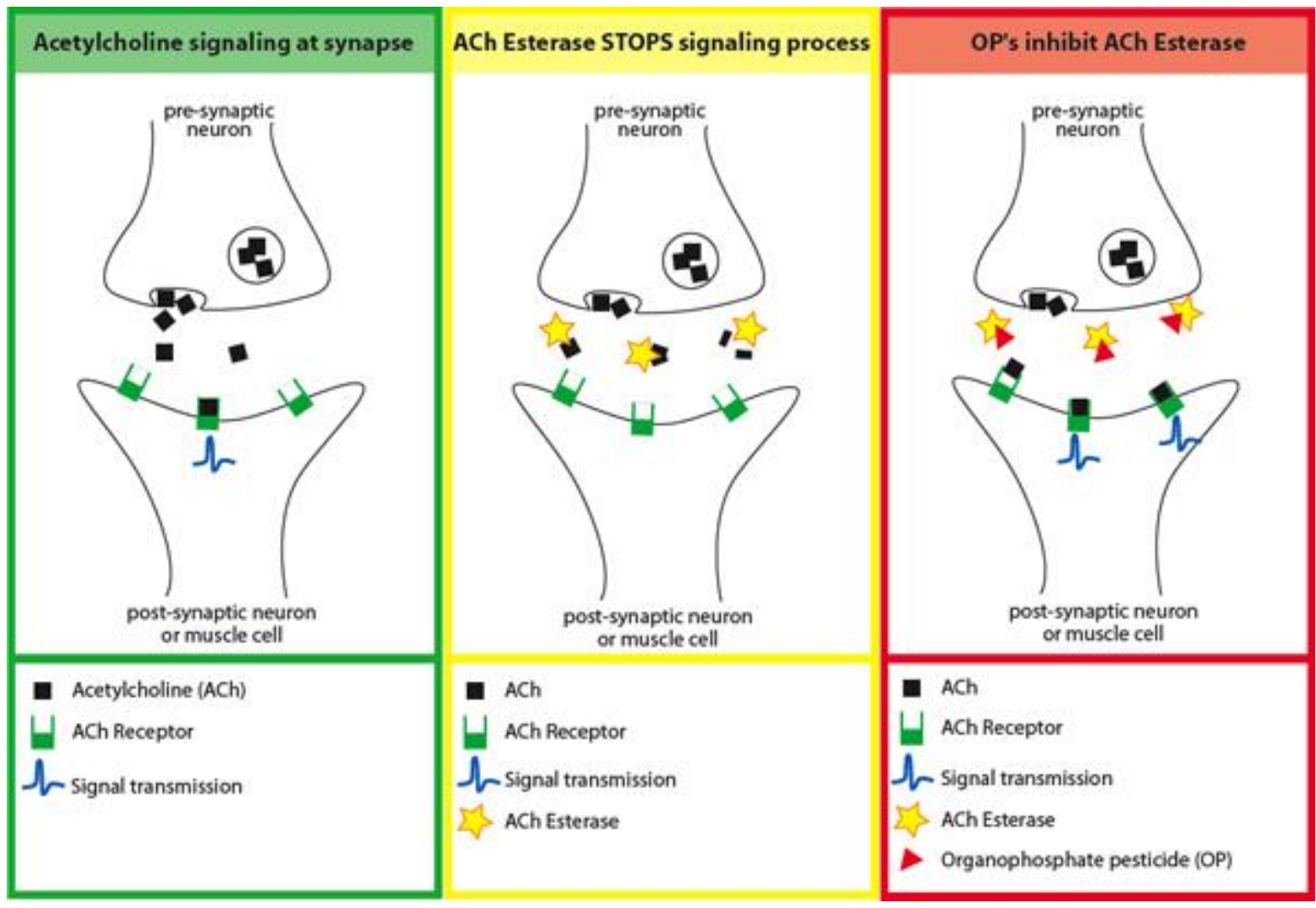

The most specific test is the inhibition of cholinesterase activity in blood. It reflects the systemic absorption of Organophosphorus compound. We can exclude the poisoning by Organophosphorus compounds when there is normal cholinesterase activity in blood. Most of the Organophosphorus compounds which are used as pesticides have the ability to inhibit both acetylcholinesterase and pseudocholinesterase.
Measurement of erythrocyte cholinesterase (acetylcholinesterase) is ideally used. Because it reflects the degree of inhibition of cholinesterase at synapse. Estimation of plasma cholinesterase (pseudo cholinesterase) has an advantage .Because it is easy and more accurate compared to estimation of RBC cholinesterase following pralidoxime administration. The effectiveness of pralidoxime is indicated by 
Erythrocyte cholinesterase. Plasma cholinesterase denotes the prior presence of cholinesterase inhibition even after recovery of erythrocyte cholinesterase activity by pralidoxime.

In acute poisoning, manifestations commonly occur only after $>50 \%$ of plasma cholinesterase is inhibited.

Clinical severity:

1)20 to $50 \%$ of normal - mild .

2) 10 to $20 \%$ of normal - moderately severe.

$3)<10 \%$ in severe poisoning.. Thus the severity of manifestations parallel the degree of inhibition of serum cholinesterase activity.

This correlation is relevant only in the initial stage of acute poisoning. On repeated exposures the inhibition is greater. The inhibition remains even after recovery from symptoms. It requires about 3-4 weeks for plasma cholinesterase to return to normal in severe poisoning . But for erythrocyte cholinesterase it takes 5 weeks or more when pralidoxime is not administered. Therefore, recovery of plasma cholinesterase seems to far more rapidly than $\mathrm{RBC}$ cholinesterase.

\section{Cholinesterase level in blood}

Serum and RBC cholinesterase levels are decreased in blood in organophosphorus poisoning. Namba T. et al (1971) first studied the correlation of serum and RBC cholinesterase activity with severity of organophosphorus poisoning. $\mathrm{He}$ described three cases of organophosphorus poisoning where presumptive diagnosis was made on the basis of patients exposure history of poisoning, characteristic cholinergic signs and symptoms and response to antidotes. Diagnosis was confirmed by measuring serum and RBC cholinesterase levels which were decreased. Anantha Krishna Ramani et al (1985) in their study correlated pseudo cholinesterase level with severity of poisoning ${ }^{46}$. However J. Sunder Ram et al (1991) and A.B. Mehta (1971) found no correlation between pseudocholinesterase activity and clinical severity ${ }^{47}$.

According to V.M. Karnik et al (1970) the severity of poisoning correlates poorly with cholinesterase level and further with treatment with atropine the clinical picture improved with cholinesterase level remaining constant. It was thought that the clinical severity was due to accumulation of acetylcholine as a result of inactivation of cholinesterase. The rate of inactivation rather than the absolute level of cholinesterase is important. Summerford (1953) showed marked reduction in cholinesterase level up to $85 \%$ in farmers without any symptoms ${ }^{48}$. He also found that farmers with mild symptoms had a rapid but small change in cholinesterase level and the severely affected persons had a rapid and large alteration. In 1995,Cunha J. et al studied 52 patients with severe organophosphate poisoning studied the importance of plasma cholinesterase (PchE) in monitoring clinical course.

Considering survivors and non-survivors, they evaluated serum cholinesterase levels at 24, 72, 120 hours and finally at discharge/death with severity scores and atropine rate. In both groups plasma cholinesterase showed a trend to increase. In survivors, PchE was statistically significant for PchE 24 - PchE 72 hr ( $\mathrm{p}=0.0008)$

PchE 24 - PchE $120 \mathrm{hr}(\mathrm{p}=0.00003)$

PchE initial - PchE $120 \mathrm{hr}(\mathrm{p}=0.002)$

In non-survivors, PchE was less than $10 \%{ }^{49}$. Hyperamylasemia is often noticed in severe organophosphate poisoning. Acute pancreatitis may follow cutaneous exposure to dimethoate or the oral ingestion of various organophosphates like parathion, malathion, difonate, coumaphos, and diazinon. Organophosphate intoxication causes excessive cholinergic stimulation of the pancreas. However, hyperamylasemia is not synonymous with acute pancreatitis.

Elevated amylase alone is not a reliable parameter in the diagnosis of organophosphateinduced pancreatitis due to its low specificity. Pancreatic isoamylase level should also be estimated to arrive at the correct diagnosis ${ }^{71,72}$. 
A retrospective study of organophosphate poisoning in the intensive care unit conducted by Matsumiya-N and Tanaka-M to analyze the incidence of respiratory failure, concluded that an increase in plasma amylase above the normal range on the day of admission was related to the development of respiratory failure .

\section{Material and Methods}

A prospective non-comparative study was undertaken in hundred patients of either sex, with history of exposure to a organophospohorous compound with clinical manifestations admitted to Thanjavur medical college and hospital, thanjavur, Tamilnadu.

The investigation protocol was submitted to the institutional ethical review board and got approval.

Informed consent was obtained. Then details of history and clinical examination were recorded.

Presumptive diagnosis of organophosphate poisoning was made according to history, clinical features and circumstantial evidence. Basic laboratory investigations were undertaken and treatment given. Clinical severity were assessed according to peradeniya organophosphorous poisoning scale.

\section{Pralidoxime}

Quarternary nitrogen

of pralidoxime

attaches here
Oxime reacts with phosphorous atom

$R$<smiles>[R]OP=O</smiles>

0

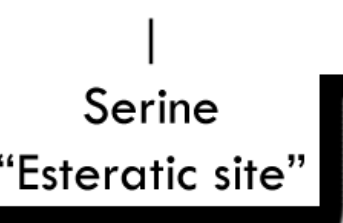

\section{Acetylcholine esterase}

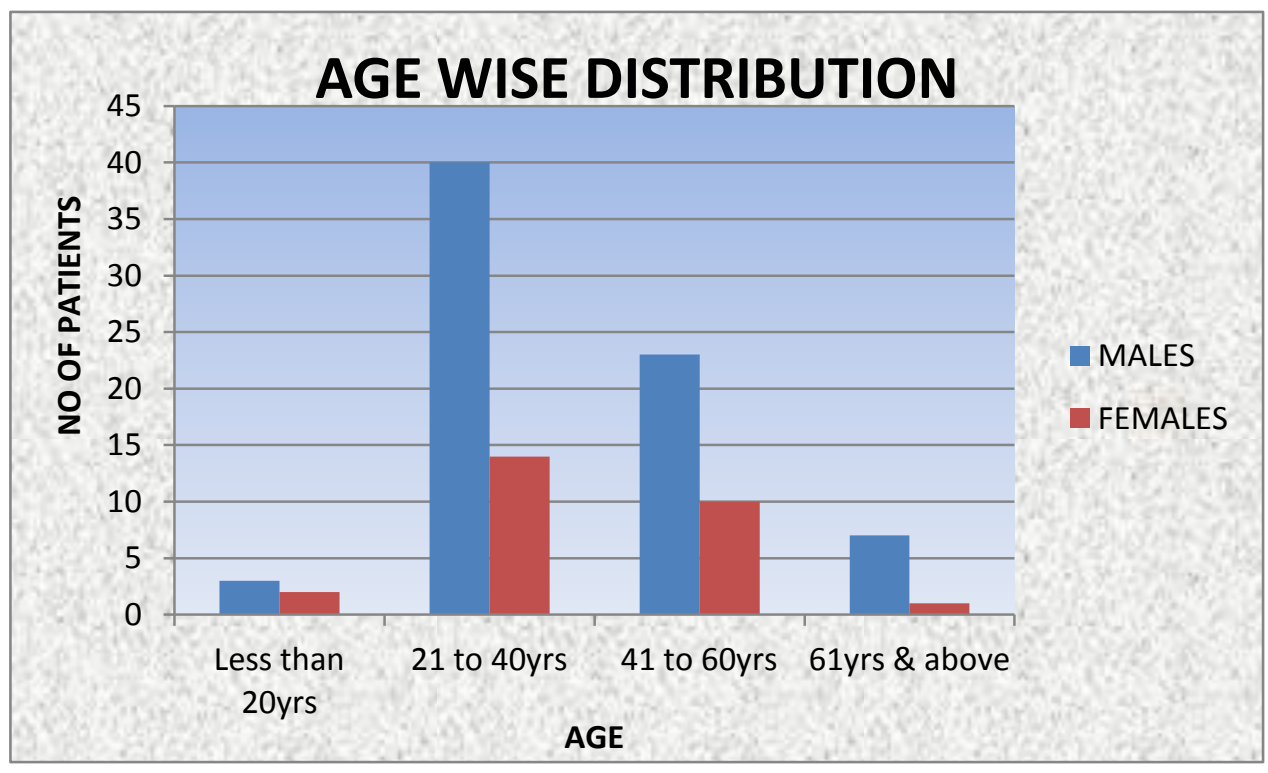




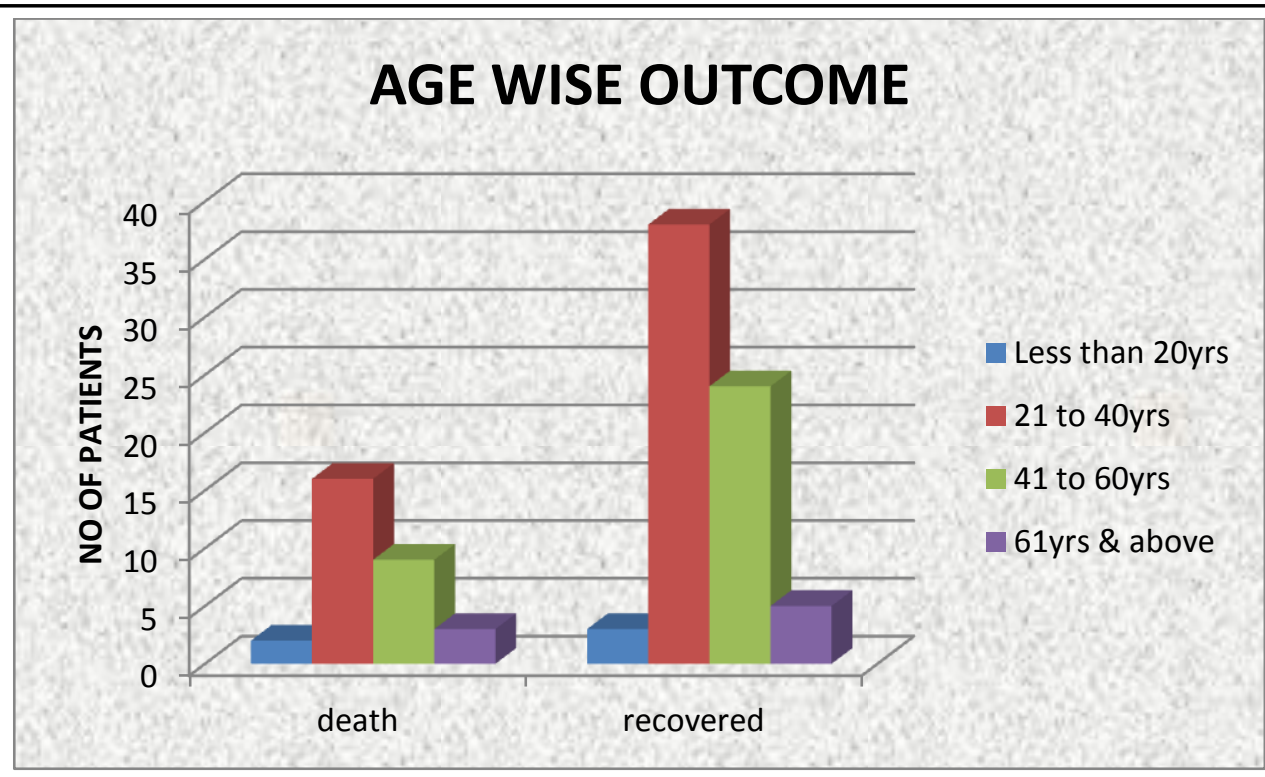

Statistical Analysis of Duration of Hospital Stay with Amylase and Pseudocholinesterase Levels Oneway ANOVA

\begin{tabular}{|c|c|c|c|c|c|c|}
\hline HOSPITAL STAY & Mean & S.D & SS & Df & MS & $\begin{array}{l}\text { Statistical } \\
\text { inference }\end{array}$ \\
\hline \multicolumn{7}{|l|}{ AMYLASE @ Admission } \\
\hline Between Groups & & & 3697505.436 & 2 & 1848752.718 & \multirow{5}{*}{$\begin{array}{c}\mathrm{F}=21.833 \\
.000<0.05 \\
\text { Significant }\end{array}$} \\
\hline Less than 10days $(n=55)$ & 545.24 & 347.444 & & & & \\
\hline 11 to 20 days $(n=39)$ & 886.82 & 197.559 & & & & \\
\hline More than 20days $(n=6)$ & 1115.33 & 205.907 & & & & \\
\hline Within Groups & & & 8213855.004 & 97 & 84678.918 & \\
\hline \multicolumn{7}{|c|}{$\begin{array}{l}\text { PSEUDOCHOLINESTERASE } \\
\text { LEVEL @ admission }\end{array}$} \\
\hline Between Groups & & & 45832629.407 & 2 & 22916314.704 & \multirow{5}{*}{$\begin{array}{c}\mathrm{F}=12.560 \\
.000<0.05 \\
\text { Significant }\end{array}$} \\
\hline Less than 10days $(n=55)$ & 2557.64 & 1708.951 & & & & \\
\hline 11 to 20 days $(n=39)$ & 1309.54 & 709.846 & & & & \\
\hline More than 20days $(n=6)$ & 689.33 & 158.349 & & & & \\
\hline Within Groups & & & 176980549.753 & 97 & 1824541.750 & \\
\hline \multicolumn{7}{|l|}{ Amylase@ 48hrs } \\
\hline Between Groups & & & 6608615.529 & 2 & 3304307.765 & \multirow{5}{*}{$\begin{array}{c}\mathrm{F}=48.448 \\
.000<0.05 \\
\text { Significant }\end{array}$} \\
\hline Less than 10days $(n=55)$ & 192.80 & 173.941 & & & & \\
\hline 11 to 20days $(n=39)$ & 590.72 & 358.915 & & & & \\
\hline More than 20days $(n=6)$ & 1086.67 & 131.707 & & & & \\
\hline Within Groups & & & 6615690.031 & 97 & 68202.990 & \\
\hline \multicolumn{7}{|c|}{ pseudocholinesterase @ 48hrs } \\
\hline Between Groups & & & 119288015.905 & 2 & 59644007.953 & \multirow{5}{*}{$\begin{array}{c}\mathrm{F}=28.305 \\
.000<0.05 \\
\text { Significant }\end{array}$} \\
\hline Less than 10days $(n=55)$ & 4438.76 & 1160.820 & & & & \\
\hline 11 to 20 days $(n=39)$ & 2647.36 & 1856.299 & & & & \\
\hline More than 20days $(n=6)$ & 837.83 & 371.507 & & & & \\
\hline Within Groups & & & 204397377.735 & 97 & 2107189.461 & \\
\hline
\end{tabular}


Statistical Analysis of Duration of Ventilator Support with Amylase and Pseudo cholinesterase Levels Oneway ANOVA

\begin{tabular}{|c|c|c|c|c|c|c|}
\hline VENTILATORY SUPPORT & Mean & S.D & SS & Df & MS & $\begin{array}{c}\text { Statistical } \\
\text { inference }\end{array}$ \\
\hline \multicolumn{7}{|l|}{ Amylase @ Admission } \\
\hline Between groups & & & 2767299.621 & 2 & 1383649.811 & \multirow{5}{*}{$\begin{array}{l}\mathrm{F}=14.678 \\
.000<0.05 \\
\text { Significant }\end{array}$} \\
\hline Less than 10days $(n=68)$ & 603.01 & 342.176 & & & & \\
\hline 11 to 20days $(n=26)$ & 906.50 & 208.560 & & & & \\
\hline More than 20days $(n=6)$ & 1115.33 & 205.907 & & & & \\
\hline Within groups & & & 9144060.819 & 97 & 94268.668 & \\
\hline \multicolumn{7}{|l|}{$\begin{array}{l}\text { Pseudocholinesterase level @ } \\
\text { Admission }\end{array}$} \\
\hline Between Groups & & & 36508107.663 & 2 & 18254053.831 & \multirow{5}{*}{$\begin{array}{c}F=9.504 \\
.000<0.05 \\
\text { Significant }\end{array}$} \\
\hline Less than 10days $(n=68)$ & 2366.40 & 1607.711 & & & & \\
\hline 11 to 20days $(n=26)$ & 1185.65 & 721.179 & & & & \\
\hline More than 20days $(n=6)$ & 689.33 & 158.349 & & & & \\
\hline Within Groups & & & 186305071.497 & 97 & 1920670.840 & \\
\hline \multicolumn{7}{|l|}{ Amylase @ 48hrs } \\
\hline Between Groups & & & 7392225.121 & 2 & 3696112.561 & \multirow{5}{*}{$\begin{array}{l}\mathrm{F}=61.474 \\
.000<0.05 \\
\text { Significant }\end{array}$} \\
\hline Less than 10days $(n=68)$ & 224.16 & 206.399 & & & & \\
\hline 11 to 20days $(n=26)$ & 707.65 & 340.065 & & & & \\
\hline More than 20days $(n=6)$ & 1086.67 & 131.707 & & & & \\
\hline Within Groups & & & 5832080.439 & 97 & 60124.541 & \\
\hline \multicolumn{7}{|l|}{ Pseudocholinesterase @ 48hrs } \\
\hline Between Groups & & & 137866871.632 & 2 & 68933435.816 & \multirow{5}{*}{$\begin{array}{l}\mathrm{F}=35.984 \\
.000<0.05 \\
\text { Significant }\end{array}$} \\
\hline Less than 10days $(n=68)$ & 4306.62 & 1251.693 & & & & \\
\hline 11 to 20days $(n=26)$ & 2097.27 & 1790.611 & & & & \\
\hline More than 20days $(n=6)$ & 837.83 & 371.507 & & & & \\
\hline Within Groups & & & 185818522.008 & 97 & 1915654.866 & \\
\hline
\end{tabular}

\section{Statistical Analysis of Outcome with Amylase and Pseudo cholinesterase Levels}

\section{T-Test}

\begin{tabular}{|c|c|c|c|}
\hline Outcome & Mean & S.D & Statistical inference \\
\hline \multicolumn{4}{|c|}{ Amylase @ Admission } \\
\hline Death $(n=30)$ & 835.13 & 302.529 & \multirow{2}{*}{$\begin{array}{c}\mathrm{T}=2.364 \mathrm{Df}=98 \\
.020<0.05 \\
\text { Significant }\end{array}$} \\
\hline Recovered $(n=70)$ & 660.17 & 353.334 & \\
\hline \multicolumn{4}{|c|}{ Pseudo Cholinesterase Level @ admission } \\
\hline Death $(n=30)$ & 1310.67 & 1127.364 & \multirow{2}{*}{$\begin{array}{c}\mathrm{T}=-2.935 \mathrm{Df}=98 \\
.004<0.05 \\
\text { Significant }\end{array}$} \\
\hline Recovered $(n=70)$ & 2236.54 & 1560.163 & \\
\hline \multicolumn{4}{|l|}{ Amylase@ 48hrs } \\
\hline Death $(n=30)$ & 758.40 & 311.313 & \multirow{2}{*}{$\begin{array}{c}\mathrm{T}=8.296 \mathrm{Df}=98 \\
.000<0.05 \\
\text { Significant }\end{array}$} \\
\hline Recovered $(n=70)$ & 248.71 & 268.068 & \\
\hline \multicolumn{4}{|c|}{ Pseudo cholinesterase @ 48hrs } \\
\hline Death $(n=30)$ & 1576.57 & 1435.003 & \multirow{2}{*}{$\begin{array}{c}\mathrm{T}=-9.943 \mathrm{Df}=98 \\
.000<0.05 \\
\text { Significant }\end{array}$} \\
\hline Recovered $(n=70)$ & 4358.70 & 1212.388 & \\
\hline
\end{tabular}




\section{Outcome}

In our study, among 100 patients 70 patients recovered and 30 patients died. The outcome is not depend on the age, gender, socioeconomic status, route, intention. The outcome is depend on the compound, time interval between exposure and admission, peradniya scale at admission, amylase level on admission \& at 48 hours, pseudo cholinesterase level on admission \& at 48 hours which were found to be statistically significant.

\section{Serum amylase and ventilator support}

By means of oneway ANOVA analysis, it was found that there is statistically significant difference between serum amylase levels in patients who needed ventilator support for less than 10 days , 11-20 days and more than 20 days.

\section{Serum amylase and duration of hospital stay}

By means of oneway ANOVA analysis, it was found that there is statistically significant difference between serum amylase levels in patients who needed hospital stay for less than 10 days, 11-20 days and more than 20 days.

\section{Serum amylase and outcome}

By means of T-test, it was found that there is statistically significant elevation in amylase level in mortality group in compared to recovered group.

\section{Serum amylase level and pseudocholinesterase level}

There is Significant negative correlation observed between Serum amylase level \& pseudo cholinesterase level.

It is observed that, patients who had prolonged need for ventilator support, prolonged duration of hospital stay and mortality had significantly elevated level of serum amylase on admission and at 48 hours .

\section{Conclusion}

- In our study there is male preponderance.

- Age groups between 21-40 years are most commonly encountered in organophosphorous poisoning.
- Higher mortality was observed in dimethoate and monocrotophos compounds.

- Higher amylase levels predicts ventilator support.

- Higher amylase levels predicts duration of hospital stay.

- Higher amylase levels directly correlated with mortality.

- To conclude serum amylase level may be estimated in all organophosphorous compound poisoning patients to assess the severity, to predict ventilator support, duration of hospital stay and mortality.

\section{Bibliography}

1. Davies JE. Changing profile of pesticide poisoning. New England Journal of Medicine 1987;316:806-808.

2. Jeyaratnam J. Pesticide poisoning: as a major global health problem. World Health Stat Q 1990;43:139-144.

3. Gossel, Thomas A. Principles of clinical toxicology 3rd ed., Raven Press New York 1994.

4. Orfila MJB Traite des poisons tines mineral, vegetal et animal on toxicology generale sous le rapports de la medicine legale Paris: Crochard;1815

5. Palmer Taylor. Anticholinesterase agents, Goodman-Gilman's The pharmacological basis of therapeutics 9th ed, McGraw Hill, New York 1996;160.

6. Stedman E. Chemical constitution and miotic action, Am. J. Physiol. 1929;90:528- 529.

7. McCombie $\mathrm{H}$ and Saunders BC Alkyl fluoro phosphanates preparation and physiological properties, Nature 1946;157(4):287-289.

8. Schrader G. Die entwickling rever insektizide auf Grindlange von organischem fluoro und phosphor verbindingen. Monographic No.62 Verlag Chemie, Winheim 1952. 